\title{
PENUNDAAN PILKADA SEBAGAI UPAYA PENCEGAHAN PENYEBARAN CORONA VIRUS DISEASE
}

\section{POSTPONEMENT OF REGIONAL ELECTION AS AN EFFORT TO PREVENT THE SPREAD OF CORONA VIRUS DISEASE}

\author{
Jamil $^{1}$, Dian Ferricha ${ }^{2}$ \\ ${ }^{1}$ Dosen Hukum Universitas Bhayangkara Surabaya \\ ${ }^{2}$ Dosen Hukum Institut Agama Islam Negeri Tulungagung \\ Jalan Ahmad Yani 114 Surabaya dan Jalan Mayor Sujadi Timur 4 Tulungagung \\ Email: jamiljurist@gmail.com
}

\begin{abstract}
One of the effects of the spread of the corona virus is the postponement of regional elections to December 2020. This is based on KPU Decree Number: 179/Pl.02-Kpt/01/KPU/III/2020. For this reason, this study will examine the legitimacy of the KPU's authority in postponing the elections and examine the considerations and legal basis of the election law whose clause contrasts with the current state of affairs. Therefore, with the normative legal research method through the legislation and concept approach, the results of this study are expected to be able to test the validity of the KPU Decree above so that the results can be used as a reference for the use of electoral authority to realize elections.
\end{abstract}

Keyword: Corona, decree, postponement of local election, authority

\section{Intisari}

Salah satu dampak penyebaran virus corona atau covid 19 yakni tertundanya pelaksanaan pemilihan kepala daerah menjadi Desember 2020. Hal ini didasarkan pada Keputusan KPU Nomor:179/P1.02-Kpt/01/KPU/III/2020. Penelitian ini akan mengkaji tentang legitimasi wewenang Komisi Pemilihan Umum (KPU) dalam menunda pilkada dan mengkaji tentang pertimbangan dan dasar hukum pilkada yang klausul pasalnya kontras dengan kondisi covid saat ini. Kajian ini menggunakan metode penelitian hukum normatif melalui pendekatan perundangundangan dan konseptual. Hasil penelitian diharapkan dapat menguji keabsahan SK KPU, sehingga hasilnya dapat menjadi acuan penggunaan wewenang penyelenggara pemilu.

Kata kunci: Corona, surat keputusan, penundaan pilkada, wewenang

\section{Latar Belakang Masalah}

Corona Virus Disease Tahun 2019 (Covid 19) tidak hanya menghentikan agenda-agenda pemerintah yang sudah terprogram melalui Rencana Kerja Pemerintah (RKP) saja tetapi juga menunda pelaksanaan Pemilihan Kepala Daerah yang seharusnya berdasarkan Pasal 201 UU Nomor 6 Tahun 2016 Juncto lampiran dalam PKPU Nomor 15 tahun 2019 dilaksanakan pada tanggal 23 September 2020. Penundaan tersebut dilakukan oleh Komisi Pemilihan Umum (KPU) pusat melalui surat Keputusan Nomor: 179/PL.02-Kpt/01/KPU /III/2020 Tentang Penundaan Tahapan Pemilihan Dan Wakil Gubernur, Bupati Dan Wakil 
Bupati Dan/Atau Walikota Dan Wakil Walikota Tahun 2020 Dalam Upaya Pencegahan Penyebaran Covid-19.

Konsideran Surat Keputusan di atas mengingatkan KPU untuk mendasarkan keputusannya pada beberapa pasal yaitu Pasal 120 dan Pasal 121 Undang Undang Nomor 1 Tahun 2015 tentang Penetapan Peraturan Pemerintah Pengganti Undang-Undang Nomor 1 Tahun 2014 tentang Pemilihan Gubernur, Bupati dan Walikota menjadi Undang-Undang (UU No. 1 Tahun 2015), dan juga Pasal 8, Pasal 10a dan Pasal 122 Undang Undang Nomor 8 Tahun 2015 Perubahan atas Undang Undang No 1 Tahun 2015 tentang Penetapan Peraturan Pemerintah Pengganti Undang-Undang Nomor 1 Tahun 2014 tentang Pemilihan Gubernur, Bupati dan Walikota menjadi Undang-Undang (UU No.8 Tahun 2015).

Bila dicermati bunyi Pasal 120 dan Pasal 121 UU No. 8 Tahun 2015, maka kedua pasal tersebut menjelaskan tentang Pemilihan Kepala Daerah (Pilkada) lanjutan dan pilkada susulan. Pilkada lanjutan adalah pelaksanaan pilkada yang sempat tertunda karena sebagian atau seluruh wilayah pemilihan terjadi kerusuhan, gangguan keamanan, bencana alam, atau gangguan lainnya yang mengakibatkan sebagian tahapan penyelenggaraan pemilihan tidak dapat dilaksanakan. Sedangkan Pilkada susulan adalah pilkada yang juga sempat tertunda karena suatu wilayah pemilihan terjadi bencana alam, kerusuhan, gangguan keamanan, dan/atau gangguan lainnya yang mengakibatkan terganggunya seluruh tahapan penyelenggaraan pemilihan, dimana yang membedakan antara Pilkada lanjutan dan Pilkada susulan adalah kalau Pilkada lanjutan tahapan yang terganggu hanya sebagian sedangkan Pilkada susulan mengganggu semua tahapan.

Mekanisme penundaan pilkada lanjutan dan pilkada susulan dijelaskan dalam Pasal 122 UU No. 8 Tahun 2015 yang berbunyi:

1) "Pemilihan lanjutan dan Pemilihan susulan dilaksanakan setelah penetapan penundaan pelaksanaan Pemilihan diterbitkan.

2) Penetapan penundaan pelaksanaan Pemilihan dilakukanoleh:

a. KPU Kabupaten/Kota atas usul PPK dalam hal penundaan pelaksanaan Pemilihan meliputi 1 (satu) atau beberapa Desa atau sebutan lain/Kelurahan;

b. KPU Kabupaten/Kota atas usul PPK dalam hal penundaan pelaksanaan Pemilihan meliputi 1 (satu) atau beberapa Kecamatan; atau

c. KPU Provinsi atas usul KPU Kabupaten/Kota dalam halpenundaan pelaksanaan Pemilihan meliputi 1 (satu) atau beberapa Kabupaten/Kota”.

Pasal 122 di atas, memberi atribusi kewenangan kepada KPU kabupaten/Kota atau KPU Provinsi dalam melakukan penundaan pilkada, sedangkan untuk KPU pusat tidak ada wewenang yang diberikan oleh undangundang tersebut untuk melakukan penundaan.

Atas hal tersebut, KPU mendasarkan pada Pasal 8 dan Pasal 10a UU No.8 Tahun 2015 yang menyatakan bahwa: 
"Penyelenggaraan Pemilihan menjadi tanggung jawab bersama KPU, KPU Provinsi, dan KPU Kabupaten/Kota” (Pasal 8). "KPU memegang tanggung jawab akhir atas penyelenggaraan Pemilihan oleh KPU Provinsi, KPU Kabupaten/Kota, PPK, PPS, KPPS, dan petugas pemutakhiran data Pemilih" (Pasal 10a).

Artinya, KPU beranggapan bahwa peran lembaganya yang dibebani sebagai penanggung jawab dan penanggung jawab akhir atas pelaksanaan pemilihan, menjadikan KPU tidak boleh berdiam diri saja manakala ada gangguan (virus corona) yang dapat menyebabkan keselamatan masyarakat termasuk penyelenggara sendiri tidak dapat terjamin atau terlindungi. Atas dasar argumentasi tersebut KPU mengambil kebijakan berupa pengeluaran surat keputusan yang pada pokoknya melakukan penundaan terhadap tahapan pilkada yang sedang berjalan. Hal tersebut tentu akan mengalami perdebatan, karena tanggung jawab dan wewenang tidak selalu memiliki interpretasi yang sama.

Berangkat dari hal tersebut, maka tulisan ini hendak mengkaji keabsahan SK penundaan Pilkada yang dikeluarkan oleh KPU. Penelitian ini mengangkat isu terkini yang dikaji secara mendalam dan kebaruannya dapat dipertanggung jawabkan. Oleh karena itu, penulis mengkaji masalah sebagai berikut yakni: Pertama, apakah virus corona saat ini termasuk gangguan yang disebutkan pada Pasal 120 dan Pasal 121 Undang-undang Nomor 1 Tahun 2015 tentang Pilkada? Kedua, apakah tanggung jawab memiliki makna sama dengan wewenang yang dimiliki oleh KPU dalam melakukan penundaan pilkada?

\section{Metode Penelitian}

Metode penelitian yang digunakan dalam tulisan ini adalah penelitian normative yaitu penelitian yang bertumpu pada data-data yang berkaitan dengan ilmu hukum seperti peraturan perundang-undangan, teori hukum, kaidah-kaidah hukum dan hal-hal lain yang berkaitan dengan isu-isu hukum. Isu-isu hukum akan dianalisis melalui pendekatan konseptual (conceptual approach) dan pendekatan perundang-undangan (statute approach).

\section{Pembahasan}

\section{a. Desain Pilkada Serentak}

Sebagaimana dalam pelaksanaan pemilihan umum (Pemilu) yang dilaksanakan secara serentak antara pemilihan kepala eksekutif dengan Pemilihan anggota Parlemen, Pemilihan Kepala Daerah juga dilaksanakan serentak antar berbagai daerah hingga semua daerah di Indonesia. Pemilihan serentak tersebut, didasarkan pada Putusan Mahkamah Konstitusi Nomor 14/PUU-XI/2013. Keserantakan pilkada yang diamanahkan oleh putusan MK tersebut, diamini oleh Undang-undang Pilkada. (UU No. 1Tahun 2015, UU No. 8 Tahun 2015 dan UU No. 10 Tahun 2016) Desain pilkada serentak dalam UU No. 1 Tahun 2015, terjadi tiga kali putaran hingga sampai tahap Pilkada serentak disemua daerah di 
Indonesia. Tiga kali putaran tersebut meliputi pilkada serentak tahun 2015, 2018, dan 2020. ${ }^{1}$

Namun dalam Undang-undang No. 10 Tahun 2016, desain pilkada serentak dirubah menjadi lima putaran yaitu: antara pilkada serentak tahun 2015, tahun 2017, tahun 2018, tahun 2020 dan tahun $2024 .{ }^{2}$ Pilkada serentak tahun 2020 merupakan pilkada serentak putaran keempat yang akan dilasanakan pada bulan September 2020 dan diperjelas kembali dalam Peraturan KPU menjadi Tanggal 23 September 2020. ${ }^{3}$ Berdasarkan Pasal 201 ayat (8) UU No. 10 Tahun 2016 Pilkada serentak Nasional diseluruh daerah di Indonesia akan dilaksanakan pada tahun 2024 yaitu berada ditahun yang sama dengan pemilu serentak.

Secara konseptual setidaknya terdapat enam model pemilu serentak, sebagai berikut: Pertama, pemilu serentak sekaligus secara total, artinya pemilu dilaksanakan satu kali dalam lima tahun untuk semua posisi di tingkat nasional hingga kabupaten/kota. Pemilu ini meliputi pemilihan legislatif (Dewan Perwakilan Rakyat (DPR), Dewan Perwakilan Daerah (DPD), Dewan Perwakilan Rakyat Daerah (DPRD) Provinsi dan Dewan Perwakilan Rakyat Daerah (DPRD) Kabupaten/Kota), pemilihan presiden, serta pilkada. Pemilu model ini sering kali disebut dengan pemilihan tujuh kotak atau "pemilu borongan". Kedua, pemilu serentak hanya untuk jabatan legislative (Pusat dan Daerah) dan kemudian disusul dengan pemilu serentak untuk jabatan sekekutif (pusat dan daerah). Dalam model clustered concurrent election ini, Pemilu untuk DPR, DPD, DPRD Provinsi dan DPRD Kabupaten/Kota dilaksanakan seperti selama ini dilakukan bersamaan sesuai waktunya, dan kemudian diikuti pemilu Presiden, Gubernur, dan Bupati, /Walikota beberapa bulan kemudian. ${ }^{4}$

Ketiga, pemilu serentak dengan pemilu sela berdasarkan tingkatan pemerintahan, diamana dibedakan waktunya untuk pemilu nasional dan pemilu daerah/local (concurrent election with mid-term election). Dalam model ini, pemilu anggota DPR, dan DPD dilaksanakan secara bersamaan dengan pemilu Presiden. Sementara pemilu DPRD Provinsi, Kabupaten/Kota dilaksanakan secara bersamaan dengan pemilihan Gubernur dan Bupati/Walikota, dua atau tiga tahun setelah pemilu nasional. ${ }^{5}$

Keempat, Pemilu serentak tingkat nasional dan tingkat local yang dibedakan waktunya secara interval (concurrent election with regional based concurrent elections). Dalam model ini, pemilihan Presiden dan pemilihan legislative untuk DPR dan DPD dilakukan secara bersamaan waktunya. Kemudian pada tahun

1 Pasal 201 Undang-undang Nomor 1 Tahun 2015 Tentang Penetapan Peraturan Pemerintah Pengganti Undang-Undang Nomor 1 Tahun 2014 Tentang Pemilihan Gubernur, Bupati, dan Walikota Menjadi Undang-Undang

2 Pasal 201 UU No. 10 Tahun 2016 Tentang Perubahan Kedua Atas Undang-Undang Nomor 1 Tahun 2015 Tentang Penetapan Peraturan Pemerintah PenggantiUndang-Undang Nomor 1 Tahun 2014 Tentang Pemilihan Gubernur, Bupati, Dan Walikota Menjadi Undang- undang.

${ }^{3}$ Lampiran PKPU Nomor 15 tahun 2019 Tentang Tahapan, Program, dan Jadwal Penyelenggaraan Pemilihan Gubernur dan Wakil Gubernur, Bupati dan Wakil Bupati, dan/atau Wali Kota dan Wakil Walikota Tahun 2020

${ }^{4}$ Ni'matul Huda dan Imam Nasef," Penataan Demokrasi \& Pemilu di Indonesia Pasca Reformasi”, Jakarta: Kencana, 2017, Hlm. 266.

${ }^{5}$ Ibid.

Suloh Jurnal Program Studi Magister Hukum, Edisi Khusus, Oktober 2020, pp. 113 - 121 
kedua diselenggarakan pemilu serentak tingkat local untuk memilih DPRD Provinsi dan Kabupaten/Kota serta pemilihan Gubernur dan Bupati/Walikota berdasarkan pengelompokan region atau wilayah kepulauan tertentu. Misal, tahun kedua khusus untuk wilayah pulau sumatera. Kemudian disusul tahun ketiga untuk wilayah pulau jawa, dan tahun keempat untuk wilayah Bali dan Kalimantan, dan tahun kelima untuk wilayah sisanya. ${ }^{6}$

Kelima, pemilu serentak tingkat nasional yang kemudian diikuti dengan pemilu serentak di masing-masing Provinsi berdasarkan kesepakatan waktu atau siklus pemilu local di masing-masing Provinsi tersebut.Dengan model concurrent election with flexible concurrent local elections ini, maka pemilihan presiden dilaksanakan secara serentak dengan pemilihan legislative untuk DPR dan DPD. Kemudian, setelahnya tergantung dari siklus maupun jadwal pemilu local yang telah disepakati bersama, diadakan pemilu serentak tingkat local untuk memilih Gubernur, Bupati, dan walikota serta memilih anggota DPRD Provinsi dan Kabupaten/Kota di satu provinsi, dan kemudian diikuti dengan pemilu serentak local yang sama di Provinsi-provinsi lainnya sehingga bisa jadi dalam setahun ada beberapa pemilu serentak local di sejumlah Provinsi. ${ }^{7}$

Keenam, Pemilu serentak untuk memilih anggota DPR, DPD, dan DPRD serta Presiden dan Wakil Presiden, kemudian diikuti setelah selang waktu tertentu dengan pemilu eksekutif bersamaan untuk satu Provinsi. Dalam pemilu ini, pemilu serentak tingkat lokal hanyalah untuk memilih Gubernur, Bupati dan Walikota secara bersamaan di suatu Provinsi, dan jadwalnya tergantung dari siklus pemilu local di masing-masing Provinsi berdasarkan hasil kesepakatan. ${ }^{8}$

Sedangkan model pemilu serentak yang ditawarkan oleh Mahkamah Konstitusi dalam putusannya Nomor 55/PUU-XVII/2019 adalah sebagai berikut:

1. Pemilihan umum serentak untuk memilih anggota DPR, DPD, Presiden/Wakil Presiden, dan anggota DPRD;

2. Pemilihan umum serentak untuk memilih anggota DPR, DPD, Presiden/Wakil Presiden, Gubernur, dan Bupati/Walikota;

3. Pemilihan umum serentak untuk memilih anggota DPR, DPD, Presiden/Wakil Presiden, anggota DPRD, Gubernur, dan Bupati/Walikota;

4. Pemilihan umum serentak nasional untuk memilih anggota DPR, DPD, Presiden/Wakil Presiden; dan beberapa waktu setelahnya dilaksanakan Pemilihan umum serentak lokal untuk memilih anggota DPRD Provinsi, anggota DPRD Kabupaten/Kota, pemilihan Gubernur, dan Bupati/Walikota;

5. Pemilihan umum serentak nasional untuk memilih anggota DPR, DPD, Presiden/Wakil Presiden; dan beberapa waktu setelahnya dilaksanakan Pemilihan umum serentak provinsi untuk memilih anggota DPRD Provinsi dan memilih gubernur; dan kemudian beberapa waktu setelahnya dilaksanakan pemilihan umum serentak kabupaten/kota untuk memilih anggota DPRD Kabupaten/Kota dan memilih Bupati dan Walikota;

6. Pilihan-pilihan lainnya sepanjang tetap menjaga sifat keserentakan pemilihan umum untuk memilih anggota DPR, DPD, dan Presiden/Wakil Presiden;

\footnotetext{
${ }^{6}$ Ibid.

${ }^{7}$ Ibid.

${ }^{8}$ Ibid.
}

Suloh Jurnal Program Studi Magister Hukum, Edisi Khusus, Oktober 2020, pp. 114 - 121 
Putusan MK di atas, memberi peluang bahwa pemilu dan pilkada yang sedianya dilaksanakan ditahun yang sama (2024) masih bisa berubah baik waktunya maupun desain keserentakannya. Apalagi, ketika memperhatikan pengalaman pemilu 2019 dengan 5 kotak surat suara yang ternyata banyak masalah, diantara masalah-masalah tersebut adalah: banyak penyelenggara yang kecapean hingga jatuh sakit bahkan meninggal dunia dan surat suara banyak yang tidak sah.

Jadwal Pilkada serentak dengan lima putaran sebagaimana telah dijelaskan dalam paragraph sebelumnya, merupakan siklus pelaksanaan pilkada serentak menuju pilkada serentak nasional diseluruh daerah di Indonesia. Pilkada tahun 2020 adalah siklus pilkada serentak terakhir sebelum pelaksanaan pilkada serentak nasional. Namun akibat Covid 19 pelaksanaan Pilkada serentak yang sedianya dilaksanakan pada tanggal 23 September Tahun 2020 oleh KPU dihentikan (ditunda) dengan mengeluarkan surat keputusan sebagaimana yang telah penulis jelaskan dalam paragraph sebelumnya.

\section{b. Wewenang Penyelenggaraan Pilkada}

Wewenang penyelenggaraan pilkada pada awalnya didesain secara berbeda dengan penyelenggaraan pemilu. Undang-undang Nomor 32 Tahun 2004 tentang Pemerintahan Daerah (UU 32 tahun 2004) meletakkan anggota Komisi Pemilihan Umum Daerah (KPUD) tidak bersifat hierarkis dengan KPU pusat karena dalam Pasal 57 UU Pemda 2004 KPUD harus bertanggung jawab kepada anggota DPRD. Berkat gugatan dari para pemantau pemilu ke mahkamah konstitusi akhirnya semua pasal dalam UU 32 tahun 2004 yang mengatur tentang pertanggung jawaban KPUD kepada DPRD dibatalkan oleh MK melalui putusan Nomor: 072-073/PUU-II/2004. Berangkat dari pembatalan tersebut, maka KPUD sebagai leading sector dalam penyelenggaraan pilkada tidak lagi dibebani pertanggungjawaban kepada DPRD dan sifat independensinya tetap kuat sebagai lembaga penyelenggara pemilu. Atas dasar itu pula hubungan struktural (heararkis) antara KPUD dan KPU pusat tetap terjaga dan diperkuat oleh berbagai pasal di UU Pemilu maupun Pilkada seperti Pasal 8 dan 10a UU Nomor 8 Tahun 2015 yang oleh KPU dijadikan dasar dalam penundaan pilkada serentak 2020.

Dalam tataran teori wewenang dibagi kedalam tigal hal yaitu Wewenang Atributif, Wewenang Delegasi dan Wewenang Mandat. Wewenang Atribusi adalah adanya pemberian suatu wewenang (baru) oleh rakyat melalui wakilnya di parlemen kepada pemerintah, dimana wewenang tersebut sebelumnya tidak dimiliki oleh pemerintah. Dengan adanya pemberian wewenang itu berarti tindakan pemerintah menjadi sah (halal) dan secara yuridis mempunyai kekuatan mengikat umum, karena telah memperoleh persetujuan dari rakyat melalui wakilnya di Parlemen yang kemudian dituangkan dalam berbagai peraturan perundang-undangan baik ditingkat pusat maupun di tingkat daerah. ${ }^{9}$ Undangundang Nomor 30 Tahun 2014 Tentang Administrasi Pemerintahan memberikan beberapa syarat pada wewenang atribusi yang meliputi:

${ }^{9}$ S.F. Marbun, Peradilan Administrasi dan Upaya Administratif di Indonesia, Yogyakarta: UII Press, 2003, hlm. 127.

Suloh Jurnal Program Studi Magister Hukum, Edisi Khusus, Oktober 2020, pp. 115 - 121 
a. Diatur dalam Undang-undang Dasar Negara Republik Indonesia Tahun 1945 dan/atau undang-undang;

b. Merupakan wewenang baru atau sebelumnya tidak ada dan

c. Atribusi diberikan kepada Badan dan/atau pejabat pemerintahan

Sedangkan delegasi dan mandat adalah terjadinya pelimpahan wewenang dari suatu badan/pejabat tata usaha yang satu kepada badan/pejabat tata usaha negara yang lainnya dalam lingkungan pemerintahan (eksekutif). Wewenang yang dilimpahkan tersebut diperoleh badan/ pejabat tata usaha negara yang melimpahkan wewenang delegasi disebut delegans dan yang menerimanya disebut delegataris, sedangkan bagi badan/pejabat tata usaha negara yang melimpahkan mandate disebut mandans dan yang menerimanya disebut mandataris. Perbedaan antara delegasi dengan mandate terdapat antara lain pada prosedur pelimpahannya, tanggungjawab dan tanggung gugatnya, serta kemungkinan dipergunakannya kembali wewenang-wewenang itu. ${ }^{10}$

\section{c. Pilkada Lanjutan dan Pilkada Susulan}

Sebagaimana penulis jelaskan dalam paragraph sebelumnya, bahwa salah satu dasar yang digunakan KPU dalam mengeluarkan SK Nomor: 179/PL.02Kpt/01/KPU /III/2020 Tentang Penundaan Tahapan Pemilihan Dan Wakil Gubernur, Bupati Dan Wakil Bupati, Dan/Atau Wali Kota Dan Wakil Wali Kota Tahun 2020 Dalam Upaya Pencegahan Penyebaran Covid-19, adalah Pasal 120 dan Pasal 121 UU Nomor 1 Tahun 2015. Pasal 120 UU Nomor 1 Tahun 2015 mengatur tentang Pilkada Lanjutan sedangkan Pasal 121 UU Nomor 1 Tahun 2015 mengatur tentang Pilkada Susulan.

Rumusan delik dalam Pilkada Lanjutan adalah "dalam hal sebagaian atau seluruh wilayah pemilihan terjadi kerusuhan, gangguan keamanan, bencana alam, atau gangguan lainya yang mengakibatkan sebagaian tahapan penyelenggaraan pemilihan tidak dapat dilaksanakan". Sedangkan rumusan delik dalam Pilkada Susulan adalah "dalam hal di suatu wilayah pemilihan terjadi bencana gangguan lainnya yang mengakibatkan terganggunnya seluruh tahapan penyelenggaraan pemilihan"

Dari rumusan Pasal 120 dan 121 di atas, dapat dibedakan antara pilkada lanjutan dan pilkada susulan. Pilkada lanjutan factor gangguannya dapat terjadi disebagian atau seluruh wilayah tetapi tahapan yang terganggu hanya sebagian saja artinya tidak sampai menghentikan semua tahapan. Sedangkan untuk Pilkada Susulan adalah foktor gangguannya terjadi hanya di suatu wilayah yang berakibat pada penghentian seluruh tahapan. Kondisi tersebut dapat dilihat tabel berikut.

\footnotetext{
${ }^{10} \mathrm{Ibid}$.
}

Suloh Jurnal Program Studi Magister Hukum, Edisi Khusus, Oktober 2020, pp. 116 - 121 
Tabel 1.

Perbedaan antara Pilkada Lnjutan dan Pilkada Susulan

\begin{tabular}{|c|c|c|}
\hline $\begin{array}{l}\text { JENIS } \\
\text { DELIK }\end{array}$ & $\begin{array}{l}\text { FAKTOR } \\
\text { GANGGUAN }\end{array}$ & $\begin{array}{c}\text { SKALA } \\
\text { GANGGUAN }\end{array}$ \\
\hline Pilkada Lanjutan & $\begin{array}{l}\text { Terjadi disebagian atau } \\
\text { seluruh wilayah }\end{array}$ & $\begin{array}{l}\text { Mengganggu sebagian } \\
\text { tahapan }\end{array}$ \\
\hline Pilkada Susulan & $\begin{array}{l}\text { Terjadi di suatu wilayah } \\
\text { (tidak seluruh) }\end{array}$ & $\begin{array}{l}\text { Mengganggu } \\
\text { tahapan }\end{array}$ \\
\hline $\begin{array}{l}\text { Penundaan Pilkada } \\
\text { Karena Covid } 19\end{array}$ & $\begin{array}{l}\text { Terjadi di } \\
\text { wilayah }\end{array}$ & $\begin{array}{l}\text { Menggangu } \\
\text { tahapan }\end{array}$ \\
\hline
\end{tabular}

Dari tabel di atas, terlihat jelas bahwa penundaan pilkada karena covid 19 tidak sesuai dengan rumusan Pasal 120 maupun 121. Penudaan pilkada karena covid 19 ini memiliki karakter sendiri yang tak tercafer oleh rumusan pasal dalam Undang-undang Pilkada. Bila dicermati bunyi pasal selanjutnya yaitu Pasal 122, maka menggunakan Pasal 120 dan/atau Pasal 121 UU No. 1 Tahun 2015 sebagai dasar penundaan pilkada dalam mencegah penyebaran covid 19 ini semakin tidak tepat karena dalam Pasal 122 ini, penetapan penudaan dilakukan oleh:

a. KPU Kabupaten/Kota atas usul PPK dalam hal penundaan pelaksanaan pemilihan meliputi 1 (satu) atau beberapa desa atau sebutan lain/kelurahan

b. KPU Kabupaten/Kota atas usul PPK dalam hal penundaan pelaksanaan pemilihan meliputi 1 (satu) atau beberapa kecamatan; atau

c. KPU Provinsi atas usul KPU Kabupaten/Kota hal penundaan pelaksanaan pemilihan meliputi 1(satu) atau beberapa kabupaten/Kota

Kejadian terkait covid 19 ini, merupakan kejadian yang tak pernah ada presedenya selama dalam sejarah kepemiluan di Indonesia serta diluar prediksi pembentuk undang-undang sehingga tidak ada aturan yang dapat dijadikan dasar bagi penyelenggara pemilu/pilkada untuk meresponya dengan sebuah kebijakan.

Namun demikian penundaan pilkada, bukan kali ini saja kejadiannya, pada Pilkada serentak tahun 2015 juga pernah ada penundaan pilkada di lima daerah yaitu di Provinsi Kalimantan Tengah, Kabupaten Fakfak di Papua, Kabupaten Simalungun dan Kota Pematangsiantar di Sumatra Utara dan Kota Manado di Sulawesi Utara. ${ }^{11}$ Penundaan tersebut dilakukan karena ada perubahan komposisi pasangan calon setelah adanya putusan Pengadilan Tata Usaha Negara. Jenis penundaan ini termasuk Pilkada lanjutan karena terjadi di semua wilayah satu kabupaten dan melanjutkannya dari tahapan yang terhenti artinya tidak dimulai dari awal kembali.

Penghentian tahapan pemilu juga terjadi pada pemilu tahun 2019 kemaren. Penghentian tersebut berkaitan dengan adanya surat suara POS yang diterima PPLN Kuala lumpur yang tercoblos duluan, sehingga atas kejadian itu Bawaslu mengeluarkan Surat Rekomendasi Nomor:

\footnotetext{
${ }^{11} \mathrm{https} / / /$ republika.co.id/berita/nz2p0j382/pilkada-lima-daerah-ditunda-kpu-inimenyulitkan diakses pada tanggal 16 mei 2020.
}

Suloh Jurnal Program Studi Magister Hukum, Edisi Khusus, Oktober 2020, pp. 117 - 121 
0968/K.BAWASLU/PM.00.00/5/2019 yang pada pokoknya meminta KPU menhentikan proses rekapitulasi hasil penghitungan perolehan suara yang sedang berlangsung untuk selanjutnya dilakukan rekapitulasi hasil penghitungan perolehan suara ulang tingkat nasional terhadap surat suara POS yang diterima PPLN Kuala Lumpur hanya untuk sejumlah 22.807 surat suara yang diterima samapi pada tanggal 15 Mei 2019; dan menyatakan surat suara tersebut tidak sah. Penghentian tahapan pemilu ini, tidak berkaitan dengan pemilu/pilkada lanjutan maupun susulan tetap masuk pada katagori pemilu ulang.

Berkaitan dengan penundaan pilkada serentak tahun 2020 yang diakibatkan covid 19 ini, pemerintah telah mengeluarkan Perppu Nomor 2 Tahun 2020 Tentang Perubahan ke Tiga Atas Undang-undang Nomor 1 Tahun 2015 Tentang Penetapan Peraturan Pemerintah Pengganti Undang-undang Nomor 1 Tahun 2014 Tentang Pemilihan Gubernur, Bupati, dan Walikota Menjadi Undang-undang (Perppu No. 2 Tahun 2020). Dalam Perppu No. 2 Tahun 2020 tersebut, delik Pilkada Lanjutan mengalami perluasan makna yaitu : "Dalam hal pada sebagian wilayah Pemilihan, seluruh wilayah Pemilihan, sebagian besar daerah, atau seluruh daerah terjadi kerusuhan, gangguan keamanan, bencana alam, bencana nonalam, atau gangguan lainnya yang mengakibatkan sebagian tahapan penyelenggaraan Pemilihan atau Pemilihan serentak tidak dapat dilaksanakan, dilakukan Pemilihan lanjutan atau Pemilihan serentak lanjutan".

Aturan dalam Pasal 120 Perppu No.2 Tahun 2020 ini, mengalami perluasan makna daripada aturan dalam Pasal 120 UU No.1 Tahun 2015, karena dalam Pasal 120 Perppu 2 Tahun 2020 ini, memasukkan bencana nonalam sebagai factor gangguan dalam penundaan pilkada, selain itu dalam Perppu ini, juga terdapat tambahan frasa "sebagaian besar daerah" dan tambahan frasa"seluruh daerah", juga ada frasa "pemilihan serentak lanjutan". Rumusan delik pilkada lanjutan sebagaimana dalam Pasal 120 Perppu No. 2 Tahun 2020 menurut penulis melegitimasi kesalahan SK Penundaan pilkada. Menurut penulis Penundaan Pilkada oleh KPU yang dsebabkan Covid 19 saat ini, baru benar (sah) manakala didasarkan pada rumusan Pasal 120 Perppu No. 2 Tahun 2020 sedangkan kalau didasarkan pada rumusan Pasal 120 UU No. 1 Tahun 2015, maka tidak sesuai dengan kasus covid-19 ini.

\section{d. Wewenang Penundaan Pilkada}

Sebagaimana yang telah penulis jelaskan dalam paragraph-paragraph sebelum ini, bahwa SK penundaan Pilkada juga didasarkan pada ketentuan dalam Pasal 8 dan Pasal 10a yang pada intinya mengatur tanggung jawab KPU sebagai penanggung jawab akhir atas terselenggaranya pilkda. Berdasarkan Pasal tersebut, KPU beranggapan bahwa tanggung jawab akhir segala pelaksanaan pilkada berada di KPU pusat, dapat dimaknai bahwa KPU juga memiliki wewenang untuk melakukan penundaan Pilkada sebagai bentuk tanggung jawab KPU atas pelaksanaan pilkada ini. 
Dalam Pasal 122 Penetapan penundaan pelaksanaan Pemilihan dilakukan oleh:

a. KPU Kabupaten/Kota atas usul PPK dalam hal penundaan pelaksanaan Pemilihan meliputi 1 (satu) atau beberapa Desa atau sebutan lain/Kelurahan;

b. KPU Kabupaten/Kota atas usul PPK dalam hal penundaan pelaksanaan Pemilihan meliputi 1 (satu) atau beberapa Kecamatan; atau

c. KPU Provinsi atas usul KPU Kabupaten/Kota dalam hal penundaan pelaksanaan Pemilihan meliputi 1 (satu) atau beberapa Kabupaten/Kota.

Dari ketentuan Pasal 122 UU No. 1 Tahun 2015 tersebut, jelas sekali bahwa KPU pusat tidak memiliki atribusi wewenang dalam mealkukan penundaan Pilkada, tetapi atas dasar tanggung jawab yang diberikan oleh Pasal 8 dan 10a UU No. 1 Tahun 2015, KPU menganggap juga memiliki wewenang.

Dalam istilah hukum sitilah tanggung jawab juga dikenal dengan istilah liability, dan responsibility. Menurut Pinto, liability dan responsibility mengandung pengertian berbeda: istilah responsibility ditujukan bagi indicator penentu atas lahirnya suatu tanggung jawab, yakni standar yang telah ditentukan terlebih dahulu dalam suatu kewajiban yang harus ditaati, serta saat lahirnya tanggungjawab itu, sedangkan istilah liability lebih menunjuk kepada akibat yang timbul dari akibat kegagalan untuk memenuhi satndar tersebut, bentuk tanggung jawab diwujudkan dalam bentuk ganti rugi kerugian dan pemulihan sebagai akibat dari terjadinya kerusakan kerugian. ${ }^{12}$

Dari pengertian tersebut dapat disimpulkan bahwa tanggung jawab dalam makna responsibility adalah mengacu pada satandart yang telah ditentukan seperti tugas, wewenang, maupun kewajiban. Artinya, bila wewenang sebagai standart ukuran sebuah tanggung jawab sudah jelas tidak diberikan oleh undang-undang, maka lembaga atau pejabat yang tidak memiliki wewenang juga terbebas dari tanggung jawab. Sedangkan tanggung jawab dalam artian liability timbul dari sebuah kegagalan dalam menjalankan standart tanggung jawab seperti gagal menjalan tugas. Adapun bentuk tanggung jawabnya dapat berupa menjalani sanksi yang diberikan. Beranjak dari hal tersebut, maka dapat penulis simpulkan bahwa tanggung jawab tidak melahirkan wewenang tetapi wewenang membutuhkan tanggung jawab. Oleh karenanya menurut penulis KPU telah salah memaknai tanggung jawab dengan makna wewenang.

Dari aspek teori hukum adminsitrasi, wewenang yang diberikan oleh undang-undang adalah wewenang atributif, sedangkan wewenang atributif tidak dapat diambil alih oleh lembaga lain meskipun bersifat structural, karena hakikatnya wewenang atributif itu merupakan wewenang asli yang diberikan rakyat melalui parlemen dalam bentuk pembuatan Undang-undang. Jadi SK penundaan Pilkada oleh KPU tidak sah secara hukum manakal wewenangnya mengacu pada Pasal 120, 121, UU No. 1 Tahun 2015 dan Mengacu pada Pasal 8 dan Pasal 10a UU No. 8 Tahun 2015.

${ }^{12}$ Lukman Hakim, Filosofi Kewenangan Organ Lembaga Daerah, Malang: Setara Press, 2012, hlm 48 .

Suloh Jurnal Program Studi Magister Hukum, Edisi Khusus, Oktober 2020, pp. 119 - 121 


\section{Penutup}

\section{a. Kesimpuan}

Penundaan Pemilihan Kepala Daerah tahun 2020 secara serentak akibat covid 19 oleh KPU RI melalui surat Keputusan Nomor: 179/PL.02-Kpt/01/KPU /III/2020 Tentang Penundaan Tahapan Pemilihan Dan Wakil Gubernur, Bupati Dan Wakil Bupati, Dan/Atau Wali Kota Dan Wakil Wali Kota Tahun 2020 Dalam Upaya Pencegahan Penyebaran Covid-19, memiliki problem Hukum sangat serius karena:

a. Tidak sesuai dengan Rumusan delik pilkada lanjutan maupun pilkada susulan sebagaimana tercantum dalam Pasal 120 dan 121 UU No. 1 Tahun 2015.

b. Tidak atribusi wewenang yang diberikan undang-undang kepada KPU.

Karena tidak ada yang mempersoalkan, bahkan antara penyelenmggara pemilu (KPU, Bawaslu dan DKPP) dengan anggota DPR (Komisi II) dan pemerintah (mendagri) sudah mensepakatinya, maka SK penundaan tersebut berlaku efektif. Namun demikian meskipun berlaku efektif secara hukum belum tentu benar.

\section{b. Rekomendasi}

KPU sebagai pejabat publik harus berhati-hati dalam menggunakan wewenang karena hal yang paling berbahaya dari pejabat public adalah penggunaan wewenang secara sembarangan (abuse of power).

\section{Buku}

\section{DAFTAR PUSTAKA}

Hakim, Lukman, Filosofi Kewenangan Organ Lembaga Daerah, Malang: Setara Press, 2012.

Huda, Ni'matul dan Imam Nasef," Penataan Demokrasi \& Pemilu di Indonesia Pasca Reformasi”, Jakarta: Kencana, 2017.

Marbun, S.F., Peradilan Administrasi dan Upaya Administratif di Indonesia, Yogyakarta: UII Press, 2003

\section{Peraturan Perundang-undangan}

Undang-Undang Nomor 10 Tahun 2016 tentang Perubahan Kedua Atas UndangUndang Nomor 1 Tahun 2015 tentang Penetapan Peraturan Pemerintah PenggantiUndang-Undang Nomor 1 Tahun 2014 tentang Pemilihan Gubernur, Bupati, Dan Walikota Menjadi Undang- undang.

Undang-Undang Nomor 1 Tahun 2015 tentang Penetapan Peraturan Pemerintah Pengganti Undang-Undang Nomor 1 Tahun 2014 Tentang Pemilihan Gubernur, Bupati, dan Walikota Menjadi Undang-Undang

Undang-Undang Nomor 32 Tahun 2004 tentang Pemerintahan Daerah

PERPU Nomor 2 Tahun 2020 Tentang Perubahan ke Tiga Atas Undang-undang Nomor 1 Tahun 2015 Tentang Penetapan Peraturan Pemerintah Pengganti Undang-undang Nomor 1 Tahun 2014 Tentang Pemilihan Gubernur, Bupati, dan Walikota Menjadi Undang-undang 
PKPU Nomor 15 tahun 2019 Tentang Tahapan, Program, dan Jadwal Penyelenggaraan Pemilihan Gubernur dan Wakil Gubernur, Bupati dan Wakil Bupati, dan/atau Wali Kota dan Wakil Walikota Tahun 2020

Putusan Mahkamah Konstitusi Nomor 14/PUU-XI/2013.

Putusan Mahkamah Konstitusi Nomor 55/PUU-XVII/2019.

\section{Internet}

https://republika.co.id/berita/nz2p0j382/pilkada-lima-daerah-ditunda-kpu-inimenyulitkan diakses pada tanggal 16 mei 2020. 